\title{
ANALISIS SIKAP DAN PROSES PENGAMBILAN KEPUTUSAN OLEH KONSUMEN SAYURAN ORGANIK DI KOTA MEDAN
}

\author{
Irada Sinta ${ }^{1}$, Emmia Tambarta Kembaren ${ }^{2}$ \\ 1,2 Universitas Malikussaleh, Aceh, Indonesia \\ Corresponding author: irada@unimal.ac.id
}

\begin{abstract}
Abstrak: Tujuan penelitian ini adalah untuk mengetahui proses pengambilan keputusan pembelian sayuran organik serta sikap konsumen terhadap sayuran organik di swalayan Berastagi Kota Medan. Penelitian ini menggunakan metode survei. Pemilihan responden ditentukan secara insidental sampling dengan jumlah responden sebanyak 30 orang. Analisis deskriptif digunakan untuk mengidentifikasi karakteristik konsumen dan mengkaji proses keputusan pembelian pada sayuran organik, dan analisis sikap multiatribut Fishbein digunakan untuk mengidentifikasi atribut dominan pada sayuran organik. Hasil analisis Fishbein memperlihatkan atribut manfaat sayuran organik mendapatkan nilai tertinggi pada tingkat kepentingan maupun tingkat kepercayaan bagi konsumen sayuran organik. Sikap konsumen secara keseluruhan memperlihatkan hasil 95,52 nilai ini terletak pada rentang kategori biasa saja. Hal ini dikarenakan manfaat sayuran organik sangat baik bagi kesehatan, namun harga untuk memperolehnya masih dirasakan sangat mahal. Berdasarkan hasil penelitian, adapun saran yang dapat diberikan adalah: (1) Pihak produsen, pemasar, serta pemerintah dapat memfokuskan peningkatan kualitas sayuran organik yang memiliki manfaat yang sangat dipertimbangkan oleh konsumen. (2) Penentuan harga yang sesuai bagi produsen maupun konsumen. (3) Peneliti selanjutnya dapat memperdalam penelitian dengan melakukan penelitian mengenai WTP (willingness to pay) terhadap sayuran organik.
\end{abstract}

Kata Kunci: pengambilan keputusan; sayuran organik; sikap konsumen

Abstract: This research aims to obtain the decision-making process in purchasing organic vegetables and consumer attitude on the organic vegetables in Berastagi Supermarket, Medan City. This research used a survey method. The respondent selection was determined by incidental sampling with the number of respondents of 30 people. The descriptive analysis was used to identify consumer characteristics and to review the decision-making process on the organic vegetables and multi-attribute attitude analysis of Fishbein which was used to identify dominant attributes on the organic vegetables. The results of Fishbein analysis showed that the attribute of organic vegetable benefit got the highest score on the level of interest and trust of the organic vegetable consumers. Overall consumer attitude showed that the result was 95.52 where this value was in the range of the normal category. This was because the benefit of organic vegetables was excellent for health, but its price on getting it was still felt to be expensive. Based on the research results, the suggestions that could be given were (1) Producers, marketers, and the government could focus on improving the quality of organic vegetables which had a well-considered benefit by the consumer. (2) Determined the appropriate prices for producers and consumers. (3) Further researchers could deepen the research by conducting research on the WTP (Willingness To Pay) for organic vegetables.

Keywords: The decision-making; organic vegetables; consumer attitude 


\section{PENDAHULUAN}

Kurun waktu 30 tahun terakhir, negara-negara industri mulai berpendapat bahwa pelaksanaan dari pertanian modern yang memberikan hasil panen yang tinggi ternyata menimbulkan dampak terhadap lingkungan. Pelaksanaan teknologi modern yang dimaksud termasuk: penggunaan varietas unggul berproduksi tinggi, pestisida kimia, pupuk kimia, dan penggunaan mesin-mesin pertanian untuk mengolah tanah serta memanen hasil. Bahaya yang ditimbulkan oleh paket pertanian modern, seperti pestisida, herbisida, dan pupuk kimia terhadap lingkungan mengakibatkan dampak negatif, pelaksanaan pertanian modern mulai mendapatkan perhatian. Sistem pertanian modern telah dianggap sebagai sistem yang berdampak buruk terhadap kualitas produk dimana jika konsumen mengkonsumsi produk tersebut maka akan berdampak negatif pada kesehatan konsumen serta sistem yang merusak atau tidak ramah lingkungan yang menyebabkan kerusakan lahan seperti penurunan kesuburan tanah.

Beberapa produk tanaman organik seperti beras dan sayuran organik mulai muncul diberbagai swalayan seperti swalayan di kota-kota besar yang salah satunya adalah kota Medan. Sayuran organik merupakan sumber pangan yang mengandung banyak gizi yang baik bagi kesehatan tubuh seperti vitamin, protein, mineral, serat, karbohidrat, dan air yang sangat berguna bagi tubuh serta tidak mengandung senyawa beracun yang dapat mengganggu kesehatan manusia. Masyarakat modern seperti saat ini pola hidup sehat menjadi salah satu ukuran standarkualitas, bukan hanya dengan melakukan olahraga. Pola hidup sehat dapat dimulai dari konsumsi makanan sehat dan mengandung gizi yang baik. Semakin jauh makanan itudari kandungan obat-obatan kimia atau pestisida, kemungkinan untuk meningkatkan standar hidup sehat akan semakin terbuka lebar.

Kesadaran akan dampak negatif penggunaan pupuk kimia dari sistem pertanian anorganik serta pentingnya gaya hidup sehat menyebabkan masyarakat mengubah pola konsumsi mereka, dari yang sebelumnya mengkonsumsi sayuran konvensionnal menjadi sayuran organik. Hal ini meningkatkan peluang pemasaran sayuran organik. Prospek usaha sayuran organik diperkirakan cukup prospektif, melihat isu-isu pertanian organik sudah mulai berkembang dengan adanya kesadaran masyarakat akan pentingnya kualitas makanan yang dikunsumsi untuk kesehatan tubuh.

Sayuran organik tidak mengandung bahan kimia yang mengganggu kesehatan manusia. Banyak gizi yang baik bagi kesehatan tubuh yang terkandung dalam sayuran organik seperti vitamin, mineral, protein, serat, dan air. Hal ini menyebabkan munculnya alternatif sikap atau perilaku masyarakat dalam mengkonsumsi bahan makanan yang lebih sehat, sehingga analisis sikap dan proses pengambilan keputusan pembelian konsumen sayuran organik penting untuk diteliti. Selain itu, swalayan di kota-kota besar seperti di kota Medan mulai banyak menawarkan produk tanaman organik seperti sayuran organik. 
Semakin banyak munculnya perusahaan dan pasar mengakibatkan tingkat persaingan yang semakin ketat serta resiko kegagalan usaha semakin besar pula. Perusahaan harus mampu mempertemukan antara apa yang ditawarkan kepada konsumen dengan apa yang diharapkan konsumennya atas produk atau jasa yang ditawarkan tersebut (Apriyani \& Sunarti, 2017). Pemasar perlu mengetahui perilaku konsumen yang akurat, data tersebut berkaitan dengan bagaimana sikap konsumen terhadap sayuran organik dan proses keputusan pembelian sayuran organik, sehingga data yang akurat dapat dijadikan pedoman bagi pihak-pihak yang berkepentingan, seperti produsen bahkan pemerintah dalam melakukan pengembangan usaha produk organik.

\section{METODE PENELITIAN}

Penelitian ini dilaksanakan di Swalyan Berastagi, Kecamatan Medan Maimun, Kelurahan Aur Kota Medan, Sumatera Utara. Swalayan Berastagi merupakan tempat penjualan yang khusus pada buah dan sayur yang di dalamnya juga terdapat produk buah dan sayuran organik di Kota Medan. Metode pengambilan sampel adalah nonprobability sampling. Teknik ini dipilih karena tidak tersedia sampling frame. Teknik sampling yang digunakan dalam metode nonprobability sampling adalah insidental sampling yaitu teknik pengambilan sampel berdasarkan kebetulan, yaitu secara insidental bertemu dengan peneliti dapat digunakan sebagai sampel, bila dipandang cocok sebagai sumber data (Sugiyono, 2019). Sampel yang menjadi responden yaitu memenuhi persyaratan yang telah ditentukan oleh peneliti, hal ini dilakukan untuk mengurangi bias penelitian. Jumlah sampel yang dipilih sebanyak 30 orang. Penentuan ini didasarkan pada jumlah minimal 30 orang secara empiris memiliki distribusi rata-rata akan mengikuti distribusi normal dan sampel tersebut sudah cukup besar.

Penelitian ini merupakan penelitian kuantitatif yaitu dengan menggunakan metode survey melalui wawancara langsung kepada para responden menggunakan kuisioner. Metode survey yaitu metode yang digunakan untuk mendapatkan data dari tempat tertentu yang alamiah (bukan buatan), tetapi peneliti melakukan perlakuan dalam pengumpulan data misalnya dengan menyebarkan kusioner dan wawancara terstruktur (Sugiyono, 2019). Variabel-variabel yang digunakan dalam penelitian ini adalah sebagai berikut (Alamsyah, 2010):

1. Variabel untuk menganalisis proses pengambilan keputusan konsumen sayuran organik adalah sebagai berikut:
a. pengenalan kebutuhan
b. pencarian informasi
c. Evaluasi alternatif
d. Pembelian
e. Evaluasi purna pembelian

2. Variabel yang digunakan untuk mengukur sikap konsumen sayuran organik adalah sebagai berikut: 

a. Rasa produk
b. harga produk
c. kemasan produk
d. manfaat produk
e. penampilan produk
f.kesegaran produk

\section{a. Uji Instrumen Penelitian}

Uji validitas adalah uji keabsahan data dalam penelitian. Validitas merupakan derajad ketepatan antara data yang terjadi pada obyek penelitian dengan daya yang dapat dilaporkan oleh peneliti. Teknik statistika yang digunakan adalah dengan rumus berikut:

$$
r_{i t}=\frac{n \sum X Y-\left(\sum X\right)\left(\sum Y\right)}{\sqrt{\left\{n \sum X^{2}-\left(\sum X\right)^{2}\left(n \sum Y^{2}-\left(\sum Y\right)^{2}\right)\right\}}}
$$

Keterangan:

rit: Koefisien korelasi butir ke -i dengan total

$X$ : Skor butir

Y : Skor total

$\mathrm{n}$ : Jumlah responden

Berdasarkan metode tersebut, jika nilai $\mathrm{r}_{\text {hitung }}>\mathrm{r}_{\text {tabel }}$ maka instrument penelitian tersebut dikatakan valid.

Uji Reliabilitas untuk mengetahui sejauh mana hasil pengukuran tetap konsisten, apabila dilakukan pengukuran dua kali atau lebih terhadap gejala yang sama dengan menggunakan alat pengukur yang sama pula. Teknik statistika yang digunakan sebagai berikut:

$$
r_{i i}=\frac{k}{k-1}\left(1-\frac{\sum \sigma i^{2}}{\sigma i^{2}}\right)
$$

Keterangan:

$r_{i i}$ : Koefisien reliabilitas instrumen

$\mathrm{k}$ : jumlah butir pertanyaan

$\sigma i^{2}$ : Varians total

$\sum \sigma i^{2}$ : jumlah varians butir

Reliabilitas adalah tingkat keandalan kuisioner. Kusioner yang reliabel adalah kuisioner yang apabila digunakan secara berulang-ulang kepada kelompok yang sama menghasilkan data yang sama. Metode pengolahan data menggunakan teknik korelasi Alpha Cronbach dengan pengolahan data menggunakan software SPSS v.20. Asumsi nilai a-Cronbach yang digunakan adalah 0,632. Jika nilai a-Cronbach hitung lebih besar dari 0,632 maka kuisioner dapat dikatakan reliebel 


\section{b. Analisis Data}

Analisis deskriptif digunakan untuk tujuan pertama penelitian yaitu mengetahui proses pengambilan keputusan dalam membeli sayuran organik di Kota Medan. Jawaban dari responden yang dominan dalam kuisioner memperlihatkan karateristik konsumen sayuran organik dan prilaku pengambilan keputusan. Analisis tersebut dirumuskan sebagai berikut:

$\mathrm{P}=\frac{f i}{\sum f i} \times 100 \%$

Keterangan:

$\mathrm{P}=$ Persentase responden yang memilih kategori tertentu

$f i=$ Jumlah responden yang memilih kategori tertentu

$\sum f i=$ Total jawaban responden

Analisis Fishbein digunakan untuk tujuan kedua penelitian yaitu menganalisis sikap konsumen sayuran organik. Secara formal model tersebut dirumuskan sebagai berikut (Peter dan Jerry, 2013):

$$
A o=\sum_{i=1}^{n} b_{i} e_{i}
$$

keterangan:

Ao = sikap keseluruhan terhadap objek

$b_{i} \quad=$ kekuatan kepercayaan bahwa objek memiliki atribut $i$

$e_{i} \quad=$ evaluasi konsumen mengenai atribut $\mathrm{i}$

$n \quad=$ jumlah atribut yang menonjol

Hasil kepercayaan dan evaluasi terhadap atribut sayuran organik oleh konsumen dikategorikan dalam rentang skala (RS). Penilain untuk setiap atribut dikategorikan dangan sangat tidak baik, tidak baik, biasa saja, baik, dan sangat baik, dicari dengan menentukan interval skor maksimum dan skor minimum yang mungkin diberikan oleh responden. Mencari rentang skala dapat dirumuskan sebagai berikut :

$$
R S=\frac{m-n}{b}
$$

Keterangan:

$\mathrm{RS}=$ rentang skala

$\mathrm{m}=$ skor maksimum yang dapat terjadi

$\mathrm{n}=\quad$ skor minimum yang dapat terjadi

$\mathrm{b}=\quad$ jumlah interpretasi (kategori) 
Skor maksimum dalam kusioner adalah 5 dan skor minimum adalah 1 dengan jumlah atribut sebanyak 7 atribut, hasil perhitungan yang dapat terjadi untuk skor maksimum adalah 175 dan skor minimum 7 sedangkan interpretasi (kategori) yang diinginkan adalah 5. Maka diperoleh hasil rentang sebagai berikut :

$R S=\frac{175-7}{5}=33,6$

Tabel 1

Intepretasi Analisis Sikap Multiatribut Fishbein

\begin{tabular}{cc}
\hline Rentang Skala & Interpretasi \\
\hline $7 \leq A o \leq 40,6$ & Sangat tidak baik \\
\hline $40,7 \leq A o \leq 74,2$ & Tidak baik \\
\hline $74,3 \leq A o \leq 107,8$ & Biasa \\
\hline $107,9 \leq A o \leq 141,4$ & Baik \\
\hline $141,5 \leq A o \leq 175$ & Sangat baik \\
\hline \multicolumn{2}{c}{ Sumber : Data primer (diolah) }
\end{tabular}

\section{HASIL DAN PEMBAHASAN}

Hasil uji instrumen penelitian berdasarkan uji validitas yang dilakukan terhadap tingkat harapan dan tingkat kepercayaan (kinerja) pada kuisioner multiatribut Fishbein. $r_{\text {tabel }}$ yang digunakan 0,632 karena kuisioner berjumlah 10 responden. Hasil uji validitas selengkapnya dapat dilihat pada Tabel 2 dan Tabel 3.

Tabel 2

Uji Validitas Tingkat Kepercayaan Model Fishbein

\begin{tabular}{ccc}
\hline Atribut & $\mathrm{r}_{\text {hitung }}$ & Keterangan \\
\hline Pertanyaan 1 & 0,968 & Valid \\
\hline Pertanyaan 2 & 0,792 & Valid \\
\hline Pertanyaan 3 & 0,635 & Valid \\
\hline Pertanyaan 4 & 0,696 & Valid \\
\hline Pertanyaan 5 & 0,968 & Valid \\
\hline Pertanyaan 6 & 0,968 & Valid \\
\hline Pertanyaan 7 & 0,968 & Valid \\
\hline
\end{tabular}

Sumber : Data primer (diolah)

Tabel 3

Uji Validitas Ttingkat Harapan Model Fishbein

\begin{tabular}{ccc}
\hline Atribut & $\mathbf{r}_{\text {hitung }}$ & Keterangan \\
\hline Pertanyaan 1 & 0,659 & Valid \\
\hline Pertanyaan 2 & 0,656 & Valid \\
\hline Pertanyaan 3 & 0,677 & Valid \\
\hline Pertanyaan 4 & 0,805 & Valid \\
\hline Pertanyaan 5 & 0,706 & Valid \\
\hline Pertanyaan 6 & 0,706 & Valid \\
\hline
\end{tabular}




\begin{tabular}{ccc}
\hline Atribut & $\mathbf{r}_{\text {hitung }}$ & Keterangan \\
\hline Pertanyaan 7 & 0,769 & Valid \\
\hline & Sumber : Data primer (diolah) &
\end{tabular}

Berdasarkan hasil pengujian reliabilitas kuisioner tingkat kepentingan diperoleh nilai 0,818 dan pada tingkat kepercayaan diperoleh niai 0,938, maka dapat dikatakan bahwa pertanyaan yang digunakan dalam kuisioner adalah reliabel.

\section{Proses Pengambilan Keputusan Oleh Konsumen}

Saat melakukan pembelian produk, konsumen akan melalui beberapa tahapan yang disebut proses keputusan pembelian oleh konsumen, proses ini terdiri dari 5 tahap yaitu, tahap pengenalan kebutuhan, tahap pencarian informasi, evaluasi alternatif, keputusan pembelian, dan perilaku purna pembelian.

\section{a. Pengenalan Kebutuhan}

Proses pembelian produk dimulai saat pembeli menyadari adanya kebutuhan, kebutuhan ini biasanya disebabkan oleh rangsangan internal maupun eksternal. Aspek yang dilihat pada tahap ini adalah motivasi serta manfaat yang diharapkan konsumen sayuran organik.

Tabel 3

Pengenalan Kebutuhan Konsumen

\begin{tabular}{|c|c|c|}
\hline Pengenalan kebutuhan & Responden & \\
\hline Motivasi Konsumen & Jumlah (Orang) & Persentase $(\%)$ \\
\hline Perwujudan gaya hidup & 6 & 20 \\
\hline Tuntutan jaman & 1 & 3,3 \\
\hline Memiliki pengetahuan & 1 & 3,3 \\
\hline Aman bagi kesehatan & 15 & 50 \\
\hline Sekedar coba-coba & 7 & 23,4 \\
\hline \multicolumn{3}{|l|}{ Manfaat yang diharapkan } \\
\hline $\begin{array}{l}\text { Pemenuhan kebutuhan gizi } \\
\text { terjamin }\end{array}$ & 16 & 53,4 \\
\hline Perwujudan gaya hidup sehat & 13 & 43,3 \\
\hline Simbol kelas social & 1 & 3,3 \\
\hline
\end{tabular}

Sumber : Data primer (diolah)

Dari jawaban responden terlihat bahwa motivasi yang paling besar mempengaruhi konsumen sayuran organik melakukan pembelian sayuran organik adalah faktor keamanan untuk kesehatan dalam mengkonsumsi sayuran organik yaitu sebesar 50\%. Motivasi ini berkaitan dengan isu-isu kesehatan pada saat ini, dimana konsumsi produk organik lebih baik dan aman untuk kesehatan tubuh. Kemudian, hasil penelitian memperlihatkan bahwa manfaat yang ingin dirasakan oleh konsumen sayuran organik adalah pemenuhan 
kebutuhan gizi yang terjamin sebesar 53,4\%. Dapat dikatakan bahwa konsumen cukup percaya akan manfaat sayuran organik yang baik dikonsumsi untuk kesehatan karena gizi yang terkandung di dalamnya.

\section{b. Pencarian Informasi}

Aspek-aspek yang diukur pada tahap ini meliputi aspek media informasi, aspek informasi yang dipertimbangkan oleh konsumen, bentuk pengaruh yang diterima oleh konsumen (responden), dan pelaku yang mempengaruhi responden.

Tabel 4

Pencarian Informasi

\begin{tabular}{|c|c|c|}
\hline Pencarian informasi & Responeden & \\
\hline Sumber informasi & Jumlah (Orang) & Persentase (\%) \\
\hline Elektronik & 17 & 56,7 \\
\hline Cetak & 8 & 26,7 \\
\hline Keluarga & 3 & 10 \\
\hline Teman & 1 & 3,3 \\
\hline Lainnya & 1 & 3,3 \\
\hline \multicolumn{3}{|l|}{ Informasi yang Menarik } \\
\hline Manfaat & 20 & 66,7 \\
\hline Gaya hidup & 7 & 23,3 \\
\hline Penampilan produk & 3 & 10 \\
\hline \multicolumn{3}{|l|}{ Pelaku yang berpengaruh } \\
\hline Keinginan sendiri & 18 & 60 \\
\hline Orang tua & 5 & 16,7 \\
\hline Saudara & 1 & 3,1 \\
\hline Teman & 6 & 20 \\
\hline \multicolumn{3}{|l|}{ Bentuk pengaruh } \\
\hline Memberitahu konsumen & 14 & 46,7 \\
\hline Menyarankan untuk membeli & 3 & 10 \\
\hline Mengajak & 1 & 3,3 \\
\hline Tidak berkomentar & 12 & 40 \\
\hline
\end{tabular}

Sumber : Data primer (diolah)

Canggihnya teknologi pada saat sekarang ini menjadikan konsumen lebih mudah mencari dan memperoleh infomasi yang mereka butuhkan. Oleh karena itu, pihak produsen perlu mempertimbangkan media informasi elektronik sebagai media yang digunakan dalam memperkenalkan produk organik.

Informasi yang paling menarik perhatian konsumen untuk melakukan pembelian adalah manfaat dari sayuran organik yaitu sebesar $66,7 \%$. Hal ini dikarenakan bahwa sayuran organik sangat baik serta aman dikonsumsi oleh konsumen, serta perhatian konsumen dalam memilih dan mengonsumsi makanan untuk kesehatan tubuh 
semakin tinggi. Berdasarkan penelitian pelaku yang paling mempengaruhi konsumen adalah keinginan diri sendiri (60\%) kemudiaan diikuti oleh pengaruh teman sebesar (20\%). Hal ini memperlihatkan bahwa konsumen mulai sadar akan kesehatan tubuh dalam mengkonsumsi makanan sehingga besar pengaruh keinginan diri sendiri untuk membeli sayuran organik.

c. Evaluasi Alternatif

Berdasarkan penelitian, aspek yang dipertimbangkan konsumen dalam pembelian sayuran organik adalah manfaat produk yaitu sebesar $73,3 \%$.

Tabel 5

Evaluasi Alternatif

\begin{tabular}{ccc}
\hline Evaluasi Alternatif & \multicolumn{2}{c}{ Responden } \\
\hline Hal yang dipertimbangkan & Jumlah (Orang) & Persentase (\%) \\
\hline Manfaat & 22 & 73,4 \\
Harga & 4 & 13,3 \\
Kandungan Gizi & 4 & 13,3 \\
\hline
\end{tabular}

Sumber : Data primer (diolah)

Hal ini berkaitan pada data-data penelitian di atas, dimana setelah konsumen mengetahui manfaat sayuran organik serta kandungan gizi yang terdapat pada produk tersebut maka hal tersebut telah menarik perhatian konsumen dan kemudian menjadi aspek yang dipertimbangkan oleh konsumen.

\section{d. Keputusan Pembelian}

Tabel 6

Keputusan Pembelian

\begin{tabular}{ccc}
\hline Keputusan Pembelian & \multicolumn{2}{c}{ Responden } \\
\hline Waktu mulai konsumsi & $\begin{array}{c}\text { Jumlah } \\
\text { (Orang) }\end{array}$ & Persentase (\%) \\
\hline 1 bulan lalu & 6 & 20 \\
2 bulan lalu & 2 & 6,7 \\
Lainnya & 22 & 73,3 \\
\hline Jumlah konsumsi & 14 & 46,8 \\
\hline 1 kali & 12 & 13,3 \\
3 kali & 1 & 3,3 \\
4 kali & 2 & 6,7 \\
Lebih dari 4 & 1 & 3,3 \\
\hline Cara memutuskan & & 40 \\
\hline Sudah direncanakan & 12 & 43,3 \\
Tergantung situasi & 13 & 16,7 \\
Mendadak & 5 & 43,3
\end{tabular}




\begin{tabular}{ccc}
\hline Keputusan Pembelian & \multicolumn{2}{c}{ Responden } \\
\hline Harga yang mahal & 14 & 46,7 \\
Kebiasaan konsumsi anorganik & 3 & 10 \\
\hline
\end{tabular}

Sumber: Data primer (diolah)

Hasil penelitian memperlihatkan bahwa konsumen telah lebih dari 3 bulan lalu mengkonsumsi sayuran organik yaitu sebesar 73,3\%. Pembelian sayuran organik oleh konsumen dilakukan sebanyak 1 kali dalam sebulan $(46,8 \%)$ dan sebanyak 3,3\% pembelian dilakukan 3 kali sebulan. Hal ini sejalan dengan penelitian yang dilakukan oleh (Alamsyah, 2010) memperlihatkan bahwa jumlah konsumsi paling dominan adalah sebanyak 1 kali hal ini dikarenakan karena harga sayuran organik masih tergolong mahal bagi sebagian besar konsumen. Konsumen sayuran organik melakukan pembelian sayuran organik tergantung pada situasi sebesar $43,3 \%$ dan diikuti pembelian secara berencana sebesar $40 \%$. Data ini memperlihatkan bahwa konsumen melakukan pembelian sayuran organik ketika pada kondisi tertentu seperti saat ingin mengkonsumsi produk tersebut atau ketika kondisi tubuh dalam keadaan sakit. Kemudian persentase terbesar diikuti dengan melakukan pembelian sayuran organik secara terencana memperlihatkan bahwa konsumen pada saat ini sudah mulai memperhatikan kesehatan tubuh dengan mengkonsumsi makanan organik secara terencana.

Faktor yang sensitif bagi para konsumen salah satunya adalah harga produk karena konsumen selalu melakukan berbagai pertimbangan ketika melakukan keputusan untuk membeli suatu produk. Konsumen akan membandingkan harga yang ditawarkan produk lain yang sejenis sebelum konsumen memutuskan untuk membeli suatu produk (Vikaliana, 2020). Faktor kendala yang dominan dirasakan konsumen dalam pembelian sayuran organik adalah harga dengan persentase $46,7 \%$. Hal tersebut memperlihatkan bahwa harga sayuran organik dikalangan konsumen masih menjadi pertimbangan serta kendala bagi konsumen untuk membeli sayuran organik setra semakin memperjelas bahwa harga sayuran organik memang masih tergolong mahal bagi beberapa konsumen jika dibandingkan dengan harga sayuran anorganik yang biasa dikonsumsi oleh konsumen. Hal ini berkaitan dengan hasil penelitian sebelumnya yang menyebabkan jumlah konsumsi konsumen dalam 1 bulan sebagian besar hanya satu kali yaitu ebesar 46,8\%, sehingga konsumen mengonsumsi sayuran organik hanya pada situasi tertentu.

\section{e. Perilaku Purna Pembelian}

Konsumen akan memiliki tingkat kepuasan yang lebih tinggi jika produk yang dikonsumsinya sesuai dengan yang diharapkan dibandingkan konsumen yang merasakan produk tersebut tidak sesuai 
dengan harapannya. Kepuasan dan ketidakpuasan seorang konsumen setelah mengkonsumsi produk (sayuran organik) akan mempengaruhi keputusan pembelian konsumen di masa mendatang.

Tabel 7

Purna Pembelian

\begin{tabular}{ccc}
\hline Purna Pembelian & \multicolumn{2}{c}{ Responden } \\
\hline Persepsi atas harga & Jumlah (Orang) & Persentase (\%) \\
\hline Mahal & 24 & 80 \\
Sepadan dengan manfaat & 4 & 13,3 \\
Murah & 2 & 6,7 \\
\hline Kepuasan secara umum & & 50 \\
\hline Biasa saja, sebab tidak ada & 15 & \\
perbedaan dengan sayuran & & 50 \\
$\quad \begin{array}{c}\text { anorganik. } \\
\text { Puas, sebab sayuran organik lebih } \\
\text { segar dan tahan lama }\end{array}$ & 15 & \\
\hline
\end{tabular}

Sumber : Data diolah

Secara umum konsumen merasakan puas setelah mengkonsumsi sayuran organik sebesar 50\% karena sayuran organik lebih lebih segar dan tahan lama. Kemudian merasa biasa saja sebesar 50\%. Persepsi konsumen yang biasa saja sebesar 50\% memperlihatkan persentase konsumen kembali membeli sayuran anorganik masih cukup besar, hal ini berhubungan dengan cara konsumen memutuskan pembelian sayuran organik yang tergantung situasi dalam pembelian sayuran organik, serta harga yang mahal menjadi kendala konsumen untuk secara konsisten mengkonsumsi sayuran organik. Hal ini dikarenakan bahwa konsumen cukup percaya dan puas atas manfaat dari sayuran organik, namun harga sayuran oganik yang masih tergolong mahal menjadi faktor kendala konsumen untuk dapat terus konsisten mengkonsumsi sayuran organik.

Pernyataan tersebut juga dipertegas pada data persepsi konsumen atas harga sayuran organik adalah mahal (80\%), kemudian sebesar $13,3 \%$ sepadan dengan manfaatnya, persentase terkecil adalah murah $(6,7 \%)$. Hasil mengenai persepsi harga pada penelitian yang dilakukan oleh Zepri pada tahun 2009 juga memperlihatkan bahwa harga masih tergolong mahal bagi konsumen.

Sikap terhadap suatu produk akan mempengaruhi tindakan atau perilaku seseorang. Penilaian konsumen terhadap atribut-atribut sayuran organik dalam bentuk nilai evaluasi $\left(e_{i}\right)$ dan nilai kepercayaan $\left(b_{i}\right)$ menentukan sikap konsumen terhadap atribut sayuran organik. 
Tabel 8

Tingkat Evaluasi Atribut Sayuran Organik

\begin{tabular}{llllllr}
\hline Atribut & \multicolumn{9}{l}{ Frekuensi Setiap Nilai Skala } & \multicolumn{2}{c}{ Skor evaluasi (ei) } \\
\cline { 2 - 7 } & $\mathbf{1}$ & $\mathbf{2}$ & $\mathbf{3}$ & $\mathbf{4}$ & $\mathbf{5}$ & 2,83 \\
\hline Rasa produk & 1 & 12 & 8 & 9 & 0 & 4,3 \\
Harga produk & 0 & 2 & 2 & 10 & 16 & 3,2 \\
Kemasan produk & 0 & 6 & 14 & 8 & 2 & 4,4 \\
Manfaat produk & 0 & 0 & 1 & 16 & 13 & 3,63 \\
Penampilan & 0 & 4 & 5 & 19 & 2 & 4,03 \\
Kesegaran & 0 & 0 & 3 & 23 & 4 & 3,6 \\
Daya tahan & 1 & 3 & 4 & 21 & 1 & \\
\hline
\end{tabular}

Sumber : Data primer (diolah)

Manfaat sayuran organic merupakan atribut yang paling penting dan diinginkan konsumen ketika membeli sayuran organik, hal ini terlihat dari atribut manfaat memiliki nilai ei tertinggi sebesar 4,4. Atribut lainnya yang dianggap penting oleh konsumen adalah atribut harga $(4,3)$ dan kesegaran sayuran organik $(4,03)$.

Harga merupakan aspek yang sangat penting bagi konsumen, karena kenyataannya harga sayuran organik lebih mahal jika dibandingkan dengan sayuran anorganik. Kesegaran sayuran organik penting bagi konsumen karena sayuran organik yang masih segar kandungan gizinya masih utuh dan manfaat bagi kesehatan lebih optimal. Sedangkan atribut rasa memiliki nilai ei paling kecil dengan 2,83 ini dikarenakan konsumen merupakan orang-orang yang pada dasarnya suka mengkonsumsi sayuran karena manfaat sayuran tersebut maka, rasa tidak terlalu penting bagi konsumen dan mereka berpendapat bahwa pada umumnya rasa sayuran sama saja.

Seberapa besar konsumen percaya bahwa suatu atribut melekat pada suatu obyek tertentu dapat dilihat dari analisis tingkat kepercayaan (bi). Semakin besar nilai kepercayaan menunjukkan bahwa konsumen semakin percaya bahwa atribut tersebut semakin melekat pada sayuran organik.

Tabel 9

Tingkat Kepercayaan Terhadap Atribut Sayuran organik

\begin{tabular}{ccccccc}
\hline \multirow{2}{*}{ Atribut } & \multicolumn{3}{c}{ Frekuensi Setiap Nilai Skala } & Skor kepercayaan (bi) \\
\cline { 2 - 8 } & $\mathbf{1}$ & $\mathbf{2}$ & $\mathbf{3}$ & $\mathbf{4}$ & $\mathbf{5}$ & \\
\hline Rasa & 0 & 0 & 13 & 17 & 0 & 3,56 \\
\hline Harga & 3 & 21 & 5 & 1 & 0 & 2,13 \\
\hline Kemasan & 0 & 6 & 13 & 7 & 4 & 3,3 \\
\hline Manfaat & 0 & 0 & 1 & 20 & 9 & 4,26 \\
\hline Penampilan & 0 & 0 & 7 & 21 & 3 & 4 \\
\hline Kesegaran & 0 & 0 & 5 & 21 & 4 & 3,96 \\
\hline Daya tahan & 0 & 1 & 6 & 22 & 1 & 3,76 \\
\hline
\end{tabular}

Sumber : Data diolah 
Manfaat sayuran organik merupakan atribut yang dipercaya konsumen berdasarkan apa yang dirasakan konsumen dengan skor kepercayaan sebesar 4,26. Pada tingkat evaluasi atribut ini juga memperoleh skor tertinggi. Ini artinya apa yang diharapkan konsumen terhadap produk sama dengan kenyataan yang dirasakan. Atribut harga mendapatkan skor terkecil, hal ini menunjukan bahwa harga sayuran organik dianggap masih tinggi yang tidak sesuai dengan harapan konsumen.

Sikap konsumen terhadap sayuran organic terbentuk dari rasa percaya konsumen bahwa manfaat yang dirasakan merupakan atribut yang paling baik dibanding atribut lain yang melekat pada sayuran organik. Sedangkan atribut harga adalah yang paling rendah bagi konsumen, karena kenyataannya harga sayuran organik sangat mahal, sehingga konsumen kurang puas terhadap atribut ini. Hal ini berkaitan dengan data penelitian mengenai proses keputusan pembelian konsumen yang memperlihatkan bahwa variabel manfaat merupakan faktor dominan yang dipertimbangkan konsumen dalam mengkonsumsi sayuran organik serta persepsi konsumen terhadap harga masih tergolong mahal yang menjadi faktor kendala paling dominan bagi konsumen dalam mengkonsumsi sayuran organik.

\section{f. Analisis Sikap Konsumen}

Nilai sikap konsumen terhadap sayuran organik di Swalayan Berastagi Kota Medan diperoleh dari hasil perkalian tingkat evaluasi kepentingan (ei) dengan tingkat kepercayaan (bi) untuk setiap atribut sayuran organik. Nilai sikap keseluruhan akan didapatkan dengan menjumlah nilai sikap seluruh atribut.

Tabel 10

Hasil Analisis Sikap Konsumen

\begin{tabular}{llrrr}
\hline No & Atribut & \multicolumn{3}{c}{ Skor sikap konsumen } \\
\cline { 3 - 6 } & & Ei & Bi & $\boldsymbol{A}_{\boldsymbol{o}}=\mathbf{e i} \mathbf{x}$ bi \\
\hline 1 & Rasa & 2,83 & 3,56 & 10,07 \\
\hline 2 & Harga & 4,3 & 2,13 & 9,15 \\
\hline 3 & Kemasan & 3,2 & 3,3 & 10,56 \\
\hline 4 & Manfaat & 4,4 & 4,26 & 18,74 \\
\hline 5 & Penampilan & 3,63 & 4 & 14,52 \\
\hline 6 & Kesegaran & 4,03 & 3,96 & 15,95 \\
\hline 7 & Daya tahan & 3,6 & 3,76 & 13,53 \\
\hline$\sum$ ei x bi & & & 95,52 \\
\hline
\end{tabular}

Sumber : Data diolah

Nilai sikap konsumen yang diperoleh adalah 95,52. Berdasarkan perhitungan skala penilaian yang telah dilakukan, maka nilai 95,52 berada pada kategori biasa saja. Hal ini menunjukkan sayuran organik 
dinilai biasa saja oleh konsumen yang memperlihatkan bahwa konsumen tidak mengharuskan dirinya mengkonsumsi sayuran organik secara konsisten atau secara terus menerus. Manfaat sayuran organik yang diberikan memang jauh lebih baik dibandingkan dengan anorganik, namun harga yang harus dibayarkan untuk membeli sayuran organik tergolong sangat mahal menjadi penyebab konsumen tidak konsisten dalam mengkonsumsi sayuran organik. Hal ini juga terlihat dari faktor kendala yang paling besar pengaruhnya bagi konsumen adalah harga sayuran organik yang lebih mahal. Penelitian yang dilakukan oleh Alamsyah (2010) juga memperlihatkan hasil nilai sikap konsumen terhadap sayuran organik tergolong pada kategori biasa saja.

\section{KESIMPULAN}

Motivasi yang paling mempengaruhi konsumen pada tahap pengenalan kebutuhan adalah bahwa sayuran organik aman bagi kesehatan dengan manfaat yang diharapkan konsumen dapat memenuhi kebutuhan gizi yang terjamin. Media yang paling banyak digunakan konsumen dalam pencarian informasi adalah media elektronik dan manfaat sayuran organik merupakan informasi yang menarik perhatian konsumen serta pelaku yang paling mempengaruhi adalah diri sendiri dan adanya bentuk pengaruh dari orang lain yang berupa pemberitahuan kepada konsumen. Aspek yang paling dipertimbangkan oleh konsumen pada tahap evaluasi adalah manfaat dari sayuran organik, dengan kendala yang dihadapi adalah harga yang mahal. Pada tahap purna pembelian terlihat bahwa konsumen telah mengkonsumsi sayuran organik lebih dari 3 bulan lalu dengan persepsi bahwa harga tergolong mahal dan kepuasan secara umum merasa biasa saja 50\% dan puas sebesar $50 \%$.

Diperoleh nilai sikap konsumen sebesar 95,52 yang berada pada kategori biasa saja. Hal ini mengindikasikan bahwa konsumen tidak akan terus konsistensi untuk selalu mengkonsumsi sayuran organik karena harga produk dianggap masih cukup tinggi, sehingga dapat dilakukan penelitian atau kajian lebih mendalam terkait WTP terhadap sayuran organik.

\section{SARAN}

Mempertahankan bahkan mengembangkan usaha sayuran organik, produsen dan pemasaran sebaiknya fokus akan peningkatan kualitas sayuran organik brokoli yang memiliki manfaat yang sangat dipertimbangkan oleh konsumen. Kendala yang dihadapi konsumen dalam pembelian sayuran organik adalah bahwa harga yang mahal bagi konsumen, sehingga sikap konsumen memperlihatkan sikap netral atas sayuran organik. Sebaiknya pemerintah dan pihak pemasar dapat menurunkan harga sayuran organik brokoli yang sesuai bagi pihak produsen serta konsumen. 
Penelitian ini masih sangat membutuhkan kajian yang lebih dalam, karena harga produk dianggap masih cukup tinggi, maka dapat dilakukan penelitian atau kajian lebih mendalam terkait WTP terhadap sayuran organik.

\section{UCAPAN TERIMA KASIH}

Terima kasih penulis sampaikan kepada seluruh narasumber yang telah membantu memberikan informasi yang diperlukan terkait penelitian ini. Ucapan terima kasih juga disampaikan kepada pemilik swalayan Berastagi Kota Medan, dinas pertanian, badan pusat statistik, seluruh intansi/lembaga atau pihak yang telah membantu menyelesaikan tulisan ini.

\section{REFRENSI}

Alamsyah, I. (2010). Analisis Perilaku Konsumen Dalam Keputusan Pembelian Sayuran Organik di Giant Taman Yasmin Bogor.

Apriyani, D. A., \& Sunarti, S. (2017). Pengaruh Kualitas Pelayanan Terhadap Kepuasan Konsumen (Survei Pada Konsumen the Little a Coffee Shop Sidoarjo). Brawijaya University.

Kuswanto, Resista Vikaliana. (2020). Pengaruh Harga dan Ulasan Produk Terhadap Keputusan Pembelian Online (Studi Kasus Pada Toko Emershop di Tokopedia.com). Jurnal Manajemen dan Bisnis Equilibrium. Vol. 6 No. 2 . hal 198-211.

Peter, P.J.dan J.C. Olson. (2013). Prilaku Konsumen dan Strategi Pemasaran. Jakarta: Salemba Empat.

Saragih, S.E. (2010). Pertanian Organik Solusi Hidup Harmoni dan Berkelanjutan. Jakarta: Penebar Swadaya.

Setiadi, N. (2013). Perilaku Konsumen. Jakarta: Kencana Prenada Media Group.

Siagian, D.dan Sugiarto. (2006). Metode Statistika Untuk Bisnis dan Ekonomi. Jakarta: PT Gramedia Pustaka Utama.

Siregar, S. (2018). Statistika Deskriptif Untuk Penelitian Dilengkapi Perhitungan Manual dan Aplikasi SPSS Versi 17. Jakarta: PTRaja Gerafindo Persada.

Sumarwan, U (2011). Perilaku Konsumen Teori dan Penerapannya Dalam Pemasaran. Bogor: Ghalia Indonesia. 
Sutanto. (2012). Penerapan Pertanian Organik. Yogyakarta: Kanisius.

Yanti, P.M.D. Lestari dan Adnyani, D.G.S. (2017). Pengaruh Kualitas Pelayanan Terhadap Kepuasan Konsumen Pada PT. POS Indonesia Cabang Gianyar. Jurnal Manajemen dan Bisnis Equilibrium. Vol. 4 No. 2 . pp 7885. Doi : https://doi.org/10.47329/jurnal_mbe.v3i2.379

Zepri, Z.Z. (2009). Analisis Karakteristik dan Prilaku Konsumen Sayuran Organik (studi kasus di HERO Supermarket Plaza Senayan, Jakarta Pusat).Skripsi. Institut Pertanian Bogor.

Sugiyono. (2019). Metode Penelitian Kuantitatif, kualitatif dan RED. Alfabeta.

Vikaliana, R. (2020). Pengaruh Harga Dan Ulasan Produk Terhadap Keputusan Pembelian Online. Jurnal Manajemen Dan Bisnis Equilibrium, 6(2), 196-209. 